\title{
Liposome Photosensitizer Formulations for Effective Cancer Photodynamic Therapy
}

\author{
Sherif Ashraf Fahmy ${ }^{1,2} \mathbb{D}$, Hassan Mohamed El-Said Azzazy ${ }^{1, *}$ and Jens Schaefer ${ }^{3, *}$ \\ 1 Department of Chemistry, School of Sciences \& Engineering, The American University in Cairo, AUC Avenue, \\ P.O. Box 74, New Cairo 11835, Egypt; sheriffahmy@aucegypt.edu \\ 2 School of Life and Medical Sciences, University of Hertfordshire Hosted by Global Academic Foundation, R5 \\ New Garden City, New Capital AL109AB, Cairo 11835, Egypt \\ 3 Department of Pharmaceutics and Biopharmaceutics, University of Marburg, Robert-Koch-Street 4, \\ 35037 Marburg, Germany \\ * Correspondence: hazzazy@aucegypt.edu (H.M.E.-S.A.); j.schaefer@staff.uni-marburg.de (J.S.); \\ Tel.: +2-02-2615-2559 (H.M.E.-S.A.); +49-6421-28-25947 (J.S.)
}

check for

updates

Citation: Fahmy, S.A.; Azzazy, H.M.E.-S.; Schaefer, J. Liposome Photosensitizer Formulations for Effective Cancer Photodynamic

Therapy. Pharmaceutics 2021, 13, 1345. https://doi.org/10.3390/

pharmaceutics13091345

Academic Editors: Udo Bakowsky, Matthias Wojcik, Eduard Preis and Gerhard Litscher

Received: 20 July 2021

Accepted: 24 August 2021

Published: 27 August 2021

Publisher's Note: MDPI stays neutral with regard to jurisdictional claims in published maps and institutional affiliations.

Copyright: (c) 2021 by the authors. Licensee MDPI, Basel, Switzerland. This article is an open access article distributed under the terms and conditions of the Creative Commons Attribution (CC BY) license (https:/ / creativecommons.org/licenses/by/ $4.0 /)$.

\begin{abstract}
Photodynamic therapy (PDT) is a promising non-invasive strategy in the fight against that which circumvents the systemic toxic effects of chemotherapeutics. It relies on photosensitizers (PSs), which are photoactivated by light irradiation and interaction with molecular oxygen. This generates highly reactive oxygen species (such as ${ }^{1} \mathrm{O}_{2}, \mathrm{H}_{2} \mathrm{O}_{2}, \mathrm{O}_{2}, \cdot \mathrm{OH}$ ), which kill cancer cells by necrosis or apoptosis. Despite the promising effects of PDT in cancer treatment, it still suffers from several shortcomings, such as poor biodistribution of hydrophobic PSs, low cellular uptake, and low efficacy in treating bulky or deep tumors. Hence, various nanoplatforms have been developed to increase PDT treatment effectiveness and minimize off-target adverse effects. Liposomes showed great potential in accommodating different PSs, chemotherapeutic drugs, and other therapeutically active molecules. Here, we review the state-of-the-art in encapsulating PSs alone or combined with other chemotherapeutic drugs into liposomes for effective tumor PDT.
\end{abstract}

Keywords: photodynamic therapy; photosensitizers; liposomes; stealth liposomes; thermosensitive liposomes; tetraether lipids; cancer

\section{Introduction}

One of the fundamental challenges in designing successful tumor-targeting approaches is the selective delivery of anticancer drugs to cancerous cells. Although both the cancerous and healthy tissues are impacted by the cytotoxic effects of anticancer drugs, most targeting approaches depend on the fact that the rapidly proliferating cancer cells would be more affected by chemotherapeutics than healthy ones [1-4]. This warrants the development of novel targeted delivery systems capable of selectively eradicating cancerous cells. Various drug delivery vehicles and nanocarriers have been developed in this context, including polymeric and metal nanoparticles, supramolecular nanocapsules, liposomes, host-guest complexes, and nanofibers [1,2,5,6]. Multimodal systems were designed by exploiting the capability of the nanosystems to co-deliver chemotherapeutic drugs and targeting entities, resulting in more efficient treatment.

Photodynamic therapy (PDT) employs pharmacologically inactive photosensitizers activated upon exposure to light in the presence of oxygen. It is a non-invasive therapeutic approach that does not require sophisticated equipment or setup and has been employed to treat cancer, cardiovascular, and skin diseases [5-15]. This review presents the basic principles and current challenges of using PDT in cancer therapy and state-of-the-art approaches in formulating liposome photosensitizers to improve the therapeutic significance of PDT. 


\section{Photodynamic Therapy in Treating Cancer}

PDT was approved in several countries for treating cancer after its approval for recurrent bladder cancer treatment by the Canadian Health Protection Branch [1]. PDT depends on the interaction of a photosensitizer (PS), delivered to target tissues, and with the light of a specific wavelength in the presence of molecular oxygen dissolved in the cytoplasm [16-22]. Upon light absorption, the PS molecules are transferred from the ground state to an excited singlet state and then to a triplet excited state via the intersystem crossing. In the triplet excited state, the PS undergoes two simultaneous reactions (1) Type I electron transfer reactions which involve the direct reaction of PS with cell components forming anionic or cationic radicals that react with molecular oxygen generating ROS, and (2) Type II energy transfer reactions which involve direct reaction of PS with molecular oxygen producing singlet oxygen $\left({ }^{1} \mathrm{O}_{2}\right)$ (Figure 1 ). The generated highly reactive ROS (such as ${ }^{1} \mathrm{O}_{2}, \mathrm{H}_{2} \mathrm{O}_{2}, \mathrm{O}_{2}, \cdot \mathrm{OH}$ ) exert their cytotoxic effects via irreversible oxidation of the cellular and subcellular organelles and induce apoptosis or necrosis, leading to cell death. ROS can also induce autophagy by several mechanisms, leading to cytoprotective and cell killing responses [23-25].

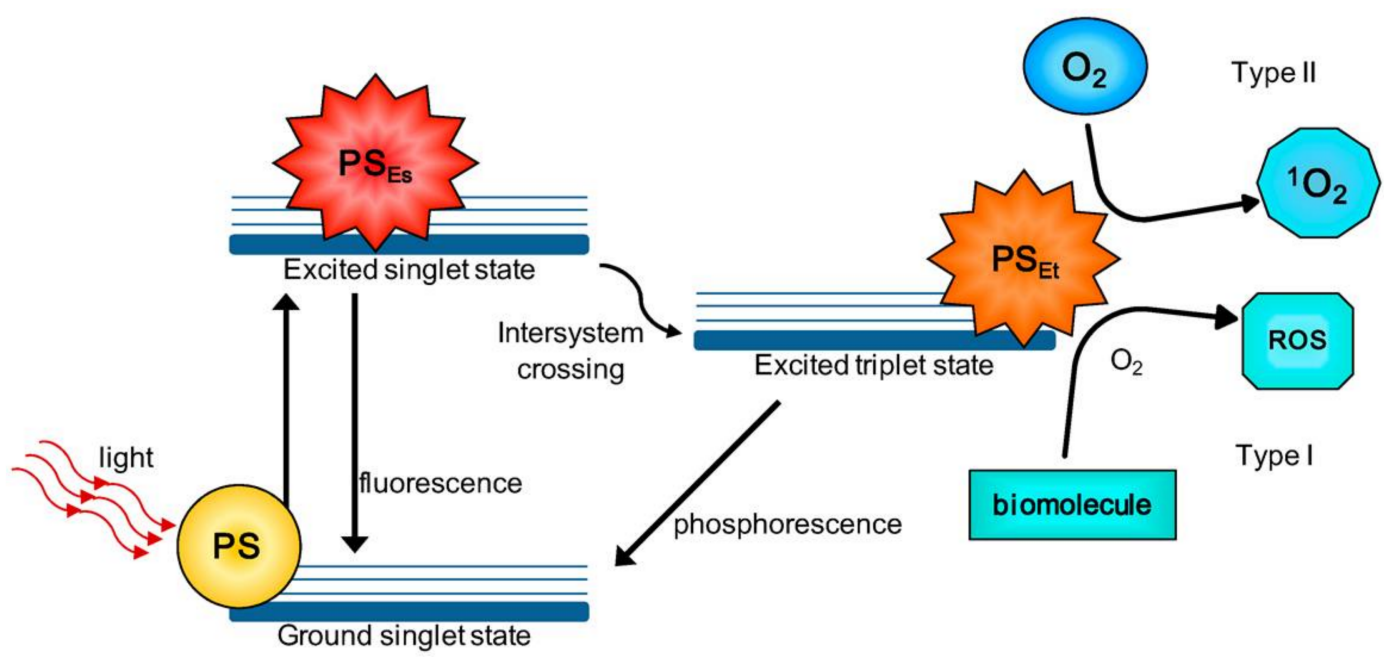

Figure 1. Mechanism of action of PDT demonstrating Type I and Type II reactions. PS $S_{E s}$, PS excited singlet state; PS excited triplet state; ROS, reactive oxygen species. Reprinted with permission from ref. [26]. 2016 Calixto et al.

Many parameters influence the effectiveness of PDT. These include the type and dose of PS, route of administration, intensity of light used, type of tumor, and concentration of dissolved cytoplasmic oxygen. The ideal PSs should be pharmacologically inactive in the absence of light irradiation, pure, water-soluble, and selectively present in tumor cells. It should have an absorption spectrum preferably between 650 and $800 \mathrm{~nm}$ and rapid elimination rates. Two classes of PSs exist: Porphyrin PSs (three generations) and nonporphyrin PSs [27]. First-generation PSs (such as hematoporphyrins) have been developed and undergone clinical trials for more than 40 years [16]. However, they suffered various drawbacks, including (i) poor tissue penetration, (ii) low chemical stability, (iii) activation when irradiated with wavelengths below $650 \mathrm{~nm}$, (iv) causing skin hypersensitivity reactions, and (v) low elimination rates and long half-lives. Most of the issues attributed to hematoporphyrins refer mainly to Photofrin. This is a complex mixture of porphyrin dimers and higher oligomers, some of which persist in the skin and result in skin photosensitization. Second-generation PSs (such as metalloporphyrins, porphycenes, purpurins, chlorins, protoporphyrins) was developed to overcome most of these shortcomings [17]. 5Aminolevulinic acid (ALA), methyl aminolevulinate (MAL; Metvix), and Hexvix/Cysview are precursors of protoporphyrin IX, which absorbs at $630 \mathrm{~nm}[28,29]$. They were granted FDA approvals and are used to treat glioblastoma, basal cell carcinoma, Bowen disease, prostate, bladder, and colon cancers [30-32]. Meta-tetrahydroxy phenyl chlorin (m-THPC, 
temoporfin), excitation wavelength of $\sim 652 \mathrm{~nm}$, is approved in the EU to treat biliary and pancreatic cancers and breast cancer metastases. Verteporfin (Visudyne), a benzoporphyrin derivative (BPD), with an excitation wavelength of $690 \mathrm{~nm}$, has been granted FDA approval to treat choroidal hemangioma and gastric cancer. Additionally, hypericin (excitation wavelength of 570-650 nm) is an FDA-approved PS for treating skin cancers (Figure 2) [33-35]. Recently, third-generation PSs have been developed by conjugation of second-generation PSs to biological targeting moieties, such as carbohydrates, peptides, or antibodies. This would enhance the selectivity of PSs and minimize undesired adverse effects $[29,36]$. Non-porphyrin PSs include psoralens, anthracyclines, chalcogenopyrylium dyes, cyanines, and phenothiazinium dyes. Despite the promising effects of PDT in cancer treatment, it still suffers from several shortcomings. These include poor biodistribution of hydrophobic PSs, poor cellular uptake, difficulty applying PDT to deep cancer tissues (hindering light penetration), and low selectivity to cancer cells [37,38]. In addition, cancer cells' oxygenation is essential to achieving effective PDT. Because cancer tissues are bordered by necrotic cells, and compact tumor masses, it is challenging to treat deep cancers using the traditional PDT. Because of the low tissue penetration of visible light, PDT is only effective for treating superficial, and skin tumors [26]. Furthermore, using photofrin may cause long-lasting photosensitivity reactions. Consequently, encapsulation of PSs within different nanocarriers has been proposed to overcome traditional PDT's shortcomings, such as improving water solubility, bioavailability, and selective targeting of PSs [39].

A
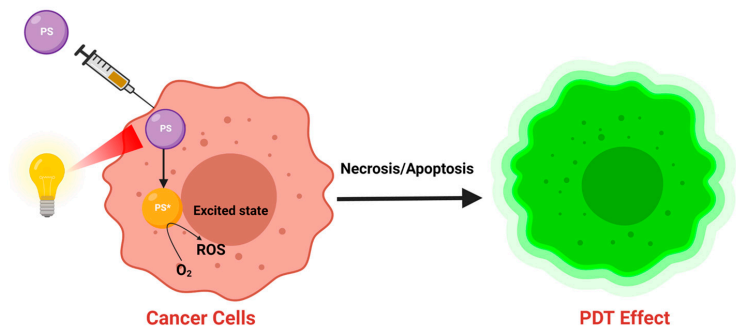

B

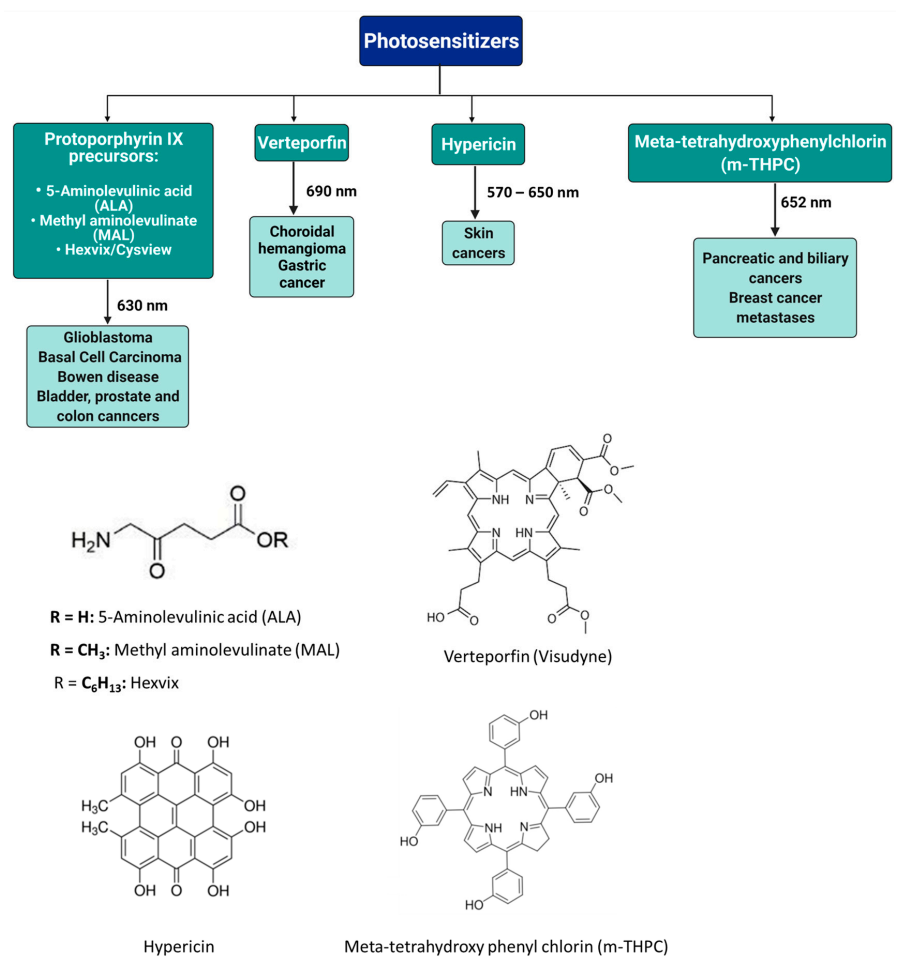

Figure 2. (A) General principle of photodynamic therapy; (B) FDA and/or EU-approved photosensitizers in cancer photodynamic therapy; (C) Chemical structures of approved photosensitizers. PS, photosensitizer; $\mathrm{PS}^{*}$, photosensitizer excited state. 


\section{Liposomal Photosensitizer Formulations for Tumor Photodynamic Therapy}

PSs have entirely or partially been encapsulated, conjugated, or immobilized onto different nanocarriers. Multimodal integration of nanocarriers, such as polymeric nanoparticles, silica nanoparticles, and nanofibers, with PSs, offers several advantages compared to traditional PDT [1-4]. These include: (i) increasing the solubility of hydrophobic PSs, and hence, improving their biodistribution, pharmacokinetics, and cellular uptake; (ii) maintaining constant release rates of PSs at the targeted tumor cells; (iii) the ability to selectively target high loading capacity enabled by the substantial surface-to-volume ratios of nanocarriers which facilitate their surface decoration with particular ligands that can target the overexpressed receptors and proteins in tumor tissues without off-target toxic effects; (iv) boosting the preferential accumulation of PSs into cancer cells via the enhanced permeability and retention (EPR) effect; and (v) expanding the clinical applications of PDT to include additional types of cancer [40-48].

Liposomes are promising nanoplatforms that could be integrated with PDT to enhance the eradication of cancer cells without affecting healthy ones. They are spherical vesicles that consist of a hydrophilic head and a hydrophobic tail. They are self-assembled in an aqueous medium, with the assistance of hydrophobic interaction, developing a sealed structure formed of one or more lamella having the hydrophilic heads oriented towards the outer surfaces of the lamella and the hydrophobic tails founding the lamella interiors. This forms an aqueous core inside the liposomes (Figure 3) [49,50]. Liposomes are prepared using diverse types of naturally occurring phospholipids, which are biocompatible and biodegradable (Table 1). The lipid composition plays a vital role in the stability of liposomes in the systemic circulation, drugs encapsulation efficiencies, and drug release at tumor sites. For instance, the use of DSPC in the liposomal formulation results in improved encapsulation efficiency and stability compared to EPC and DPPC. This is because of the lengthy fatty acid chain of DSPC and the rigidity of the acyl chains of DSPC. Moreover, the use of cholesterol enhances liposomal stability and inhibits the undesirable drug in the systemic circulation. The inclusion of DPPE mPEG5000 in the lipid composition prolongs the blood circulation time of the liposomes, due to the additional steric hindrance created. This reduces liposomal uptake by the reticuloendothelial system. Moreover, the fusogenic features of some lipids (such as DPPG) in the liposomal membrane are reported to improve the ability of liposomes to cross the cancer cell membrane [51,52].

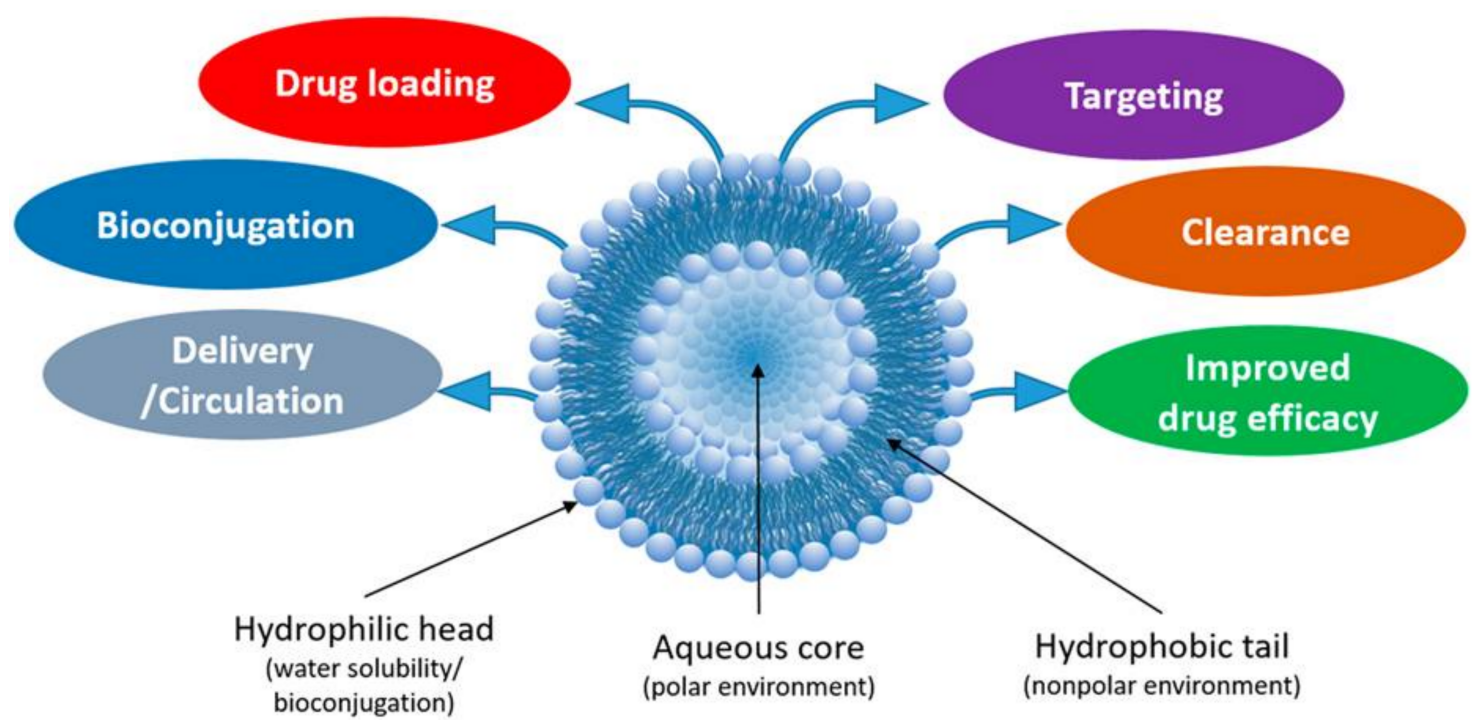

Figure 3. Liposomes are spherical vesicles with an aqueous inner core enclosed by one or more phospholipid bilayers which permit the conjugation of various functional groups. Reprinted with permission from ref. [49]. 2020 Almeida et al. 
Table 1. Chemical structure and charge of the most common lipids used in liposomal formulations.

Lipid

HSPC

L- $\alpha$-Phosphatidylcholine, hydrogenated (Soy)

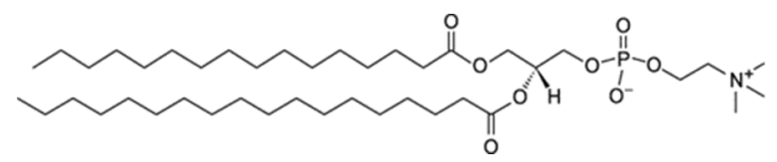

Zwitterion

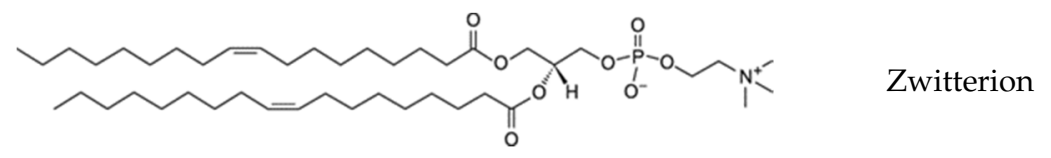

DOPC

1,2-Dioleoyl-sn-glycero-3phosphocholine

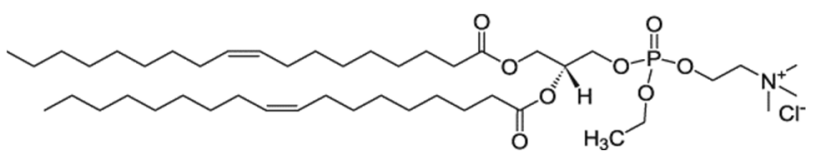

Zwitterion

EPC

1,2-Dipalmitoyl-sn-glycero-3ethylphosphocholine (chloride salt) O $\mathrm{H}_{3} \mathrm{C}$

,2-Distearoyl-sn-glycero-3phosphoglycerol, sodium salt

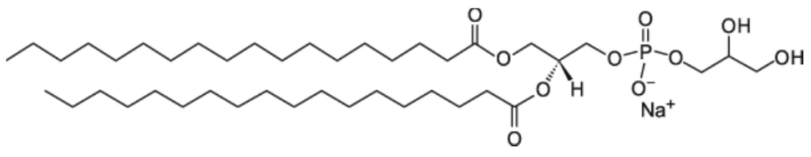

Anionic

DSPG

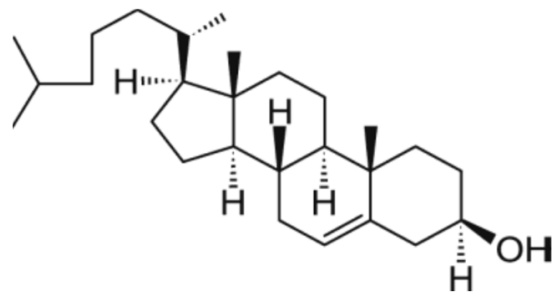

Neutral

Chol

Cholesterol

1,2-Distearoyl-sn-glycero-3-

DPPE phosphoethanolamine-N-

mPEG5000

[methoxy (polyethylene glycol)-2000] (sodium salt)

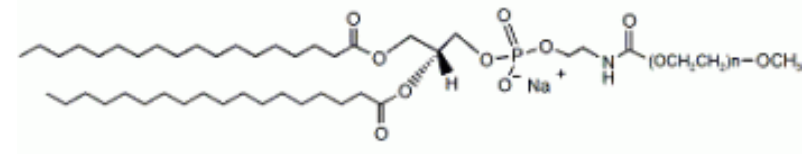

Anionic

Liposomes have unique biological and physicochemical properties setting them apart from other nanoparticles. They are prepared by the self-assembly of phospholipids and/or tetraethers lipids which are biocompatible and biodegradable [44]. Moreover, liposomes can: (i) Accommodate hydrophilic and hydrophobic agents (such as proteins, nucleic acids, chemotherapeutics, and various PSs); (ii) be decorated and bioconjugated with various functional groups and surface targeting moieties (such as proteins, polymers, and peptides), which would improve their physicochemical properties, drug loading, clearance and/or trigger the release of their cargos into the target tissue; (iii) minimize the opsonization phe- 
nomenon by being less identifiable by the reticuloendothelial system leading to prolonging the half-life of the host molecules in the systemic circulation $(>48 \mathrm{~h})$ and facilitating the preferential passive accumulation inside tumor tissues; and (iv) widen the therapeutic index for most drugs (Figure 3) [44-49]. Liposomes can enter the cancer cells either by endocytosis or via membrane fusion. For instance, liposomes containing anionic phospholipids display faster endocytosis which augments their intracellular uptake. Moreover, liposomes containing fusogenic lipids demonstrate the ability to fuse and penetrate the cancer cell membrane. A recent publication examined the pathways of cellular internalization of liposomes [50].

It is worth mentioning that proteins in the circulation adsorb to liposomes administered systemically, leading to the formation of a protein corona that interacts with immunoglobulins, complement proteins, and phagocytes in the circulation. This would stimulate cytokine production in the tumor microenvironment leading to adaptive antitumor immunity. Moreover, the interaction of liposomes with serum proteins (specially opsonins) plays an essential role in the rapid clearance of liposomal by phagocytes in the blood, liver, and spleen. PEGylation slows the release of liposomes leading to prolongation of their half-lives [53,54].

Various liposomal formulations which improved the physicochemical properties and pharmacokinetics of cancer drugs have received FDA approval (Table 2). Similar liposomal formulations encapsulating PSs can be investigated for improved cancer PDT.

Table 2. FDA-approved liposomal-based formulations in cancer treatment [52].

\begin{tabular}{|c|c|c|c|c|}
\hline Name & Approval Year & $\begin{array}{c}\text { Lipid } \\
\text { Composition }\end{array}$ & $\begin{array}{c}\text { Chemotherapeutic } \\
\text { Drug }\end{array}$ & Clinical Use \\
\hline Doxil $^{\circledR}$ & 1995 & $\begin{array}{c}\text { HSPC, } \\
\text { Cholesterol, and } \\
\text { PEG 2000-DSPE }\end{array}$ & Doxorubicin & $\begin{array}{c}\text { Ovarian and Breast } \\
\text { cancers }\end{array}$ \\
\hline DaunoXome ${ }^{\circledR}$ & 1996 & $\begin{array}{l}\text { DSPC and } \\
\text { Cholesterol }\end{array}$ & Daunorubicin & Kaposi's Sarcoma \\
\hline Depocyt $^{\circledR}$ & 1999 & $\begin{array}{c}\text { DOPC, DPPG, } \\
\text { Cholesterol and } \\
\text { Triolein }\end{array}$ & Cytarabine/Ara-C & $\begin{array}{l}\text { Neoplastic } \\
\text { meningitis }\end{array}$ \\
\hline Myocet $^{\circledR}$ & 2000 & $\begin{array}{c}\text { EPC and } \\
\text { Cholesterol }\end{array}$ & Doxorubicin & $\begin{array}{l}\text { Metastatic breast } \\
\text { cancer in } \\
\text { combination with } \\
\text { cyclophosphamide }\end{array}$ \\
\hline Mepact $^{\circledR}$ & 2004 & DOPS and POPC & Mifamurtide & $\begin{array}{l}\text { Non-metastatic } \\
\text { osteosarcoma }\end{array}$ \\
\hline Marqibo $^{\circledR}$ & 2012 & $\begin{array}{c}\text { SM and } \\
\text { Cholesterol }\end{array}$ & Vincristine & Acute leukemia \\
\hline Onivyde ${ }^{\mathrm{TM}}$ & 2015 & $\begin{array}{c}\text { DSPC: DPPE } \\
\text { mPEG5000 }\end{array}$ & Irinotecan & $\begin{array}{c}\text { Metastatic } \\
\text { pancreatic cancer }\end{array}$ \\
\hline
\end{tabular}

\subsection{Liposomes for Photodynamic Tumor Therapy}

Several liposomes encapsulating anticancer drugs and carrying targeting moieties (such as mab, glutathione, EndoTAG-1, and transferrin) are currently in clinical trials [55]. In PDT, liposomes can target the loaded PSs to cancer cells via active or passive mechanisms. Active targeting is achieved by decorating the liposomal surface with ligands (such as antibodies) that recognize and bind to overexpressed receptors and proteins in tumor tissues, such as folate, estrogen, spermine, and galactose receptors. Passive targeting takes place via the EPR effect. Blood vessels in healthy tissues are organized and tightly packed, which prevents the extravasation of liposomes. On the other hand, the blood vessels of tumor tissues are disorganized, due to the rapid proliferation of the vascular endothelium 
inside the tumor tissues [44-56]. Furthermore, the lymphatic drainage is impaired inside the tumor tissue, resulting in the overexpression of permeability mediators, such as bradykinin, nitric oxide, and prostaglandins, which increase EPR [56]. Consequently, nanoliposomes (100-300 nm) can passively cross the loose tumor endothelial barrier through the small open junctions and accumulate inside tumor tissues by the EPR effect $[44,56]$.

Several recent studies have reported the design, optimization, and use of various types of liposomes as nanocarriers for PSs alone or combined with other chemotherapeutic agents, for effective cancer PDT [38,39].

\subsubsection{Tetraether Lipid-Based Liposomes}

Tetraether lipids have longer lipophilic chains that contain ethers bonds, and hence, show high stability and lower susceptibility to oxidation. Thus, the use of tetraether lipid-based liposomes can increase liposomal membrane stability and integrity [45,56].

Curcumin, with an absorption spectrum of $300-500 \mathrm{~nm}$, is a promising natural PS that could be used safely (at doses up to $12 \mathrm{~g} / \mathrm{kg} /$ day) in PDT of superficial tumors. Reported studies demonstrate the ability of cancer cell lines to preferentially uptake a curcumin composite compared to normal cell lines. Upon its photoactivation, curcumin (in micromolar concentrations) produces capable of killing cancer cells to treat local superficial infections and cancers $[57,58]$. Duse et al. developed tetraether lipid-based (TELs) liposomes loaded with curcumin to kill cancer cells selectively [59]. Liposomes were designed by preparing a molar ratio of 90 DSPC:10 TELs using the thin-film hydration method followed by sonication at $56^{\circ} \mathrm{C}$. The curcumin-loaded liposomes had a size of about $208 \mathrm{~nm}$, a zeta potential of $-5.9 \pm \mathrm{mV}, \%$ encapsulation efficiency (\%EE) of $91 \%$, and pronounced stability attributed to the tetraether lipids, which are reported to increase membrane stability and integrity. Furthermore, the curcumin liposomes showed the highest photocytotoxicity on SK-OV-3 ovarian carcinoma cells with a radiation fluence of $13.2 \mathrm{~J} / \mathrm{cm}^{2}$ for the light-induced PDT (IC50 of $8.7 \mu \mathrm{M}$ ). Moreover, the prepared curcumin-loaded liposomes were found to have a minimal hemolytic effect $(<40 \%)$ and a coagulation time of only $9.7 \mathrm{~s}$ compared to $112 \mathrm{~s}$ in the case of free curcumin [59].

The in vitro anticancer activities of the prepared curcumin-TEL liposomes were further investigated against cervical cancer cells and papillomavirus-related cancer cell lines [60]. The cancer cell lines were incubated with the designed liposomes at various concentrations ranging from 0 to $100 \mu \mathrm{mol} / \mathrm{L}$ for $4 \mathrm{~h}$ followed by LED irradiation at $457 \mathrm{~nm}$ for 45, 136, and $227 \mathrm{~s}$ at a fluence of 1,3 , and $5 \mathrm{~J} / \mathrm{cm}^{2}$. The cytotoxic effects were then evaluated using the MTT, SYTO9/PI (propidium iodide), Annexin V-FITC (fluorescein isothiocyanate), clonogenic survival, and scratch (wound closure) assays against three different cancer cell lines (HeLa, UD-SCC-2, and VX2). The findings showed enhanced cytotoxicity at a light fluence of $3 \mathrm{~J} / \mathrm{cm}^{2}$ (IC50 values of $9.52 \mu \mathrm{mol} / \mathrm{L}, 7.88 \mu \mathrm{mol} / \mathrm{L}$, and $20.70 \mu \mathrm{mol} / \mathrm{L}$ against HeLa, UD-SCC-2, and VX2 cancer cell lines, respectively), reduced colony formation, proliferation, and cell migration rates. Liposomes loaded with curcumin was suggested as an efficient treatment of papillomavirus-associated cancers.

Plenagl et al. reported tetraether liposomes prepared with a molar ratio of 90 DPPC: 10 TELs encapsulating either hypericin (Hyp-TEL) using thin-film hydration method or hypericin-hydroxypropyl- $\beta$-cyclodextrin inclusion complex (HPCD-Hyp-TEL) through dehydration-rehydration vesicle technique [61]. The inclusion of hypericin in hydroxypropyl- $\beta$-cyclodextrin in liposomes prevents its photodegradation. The designed Hyp-TEL had an average particle size of $127 \pm 14 \mathrm{~nm}$, a zeta potential of $-2 \pm 1 \mathrm{mV}, \%$ encapsulation efficiency ( $\% E E$ ) of $82.5 \pm 2.8$. At the same time, the HPCD-Hyp-TEL had an average particle size of about $212 \pm 13 \mathrm{~nm}$, a zeta potential of $-56 \pm 1 \mathrm{mV}, \%$ encapsulation efficiency $(\% E E)$ of $81.6 \pm 3.2$. The $\% E E$ of hypericin was enhanced by increasing the liposomal membrane stability upon the addition of TEL [62]. The phototoxic effect of the prepared liposomes was evaluated on SK-OV-3 cancer cells using an LED fluence of $12.4 \mathrm{~J} / \mathrm{cm}^{2}$. The IC50 values of Hyp-TEL and HPCD-Hyp-TEL were found to be 48 and $136 \mathrm{nM}$, respectively. Furthermore, considerable amounts of hypericin were uptaken by 
cancer cells as supported by confocal laser scanning microscopy results. The designed liposomes were hemocompatible and showed a coagulation time range of 5-12 s. These results support the use of integrated liposomal/PDT in cancer-targeted therapy.

Tetraether liposomes were also used to encapsulate protoporphyrin IX PS for vascular targeting and cancer treatment using PDT [63]. The liposomes, designed using $62 \mathrm{~mol} \%$ TELs, had an average size of $170 \mathrm{~nm}$ and an average zeta potential $-42 \mathrm{mV}$. A significant improvement of protoporphyrin IX phototoxicity (IC50 of $5 \mu \mathrm{M}$ ), when loaded in TEL liposomes and tested against SK-OV-3 cancer cells (irradiated with LED light of $672 \mathrm{~mJ} / \mathrm{cm}^{2}$ ). On the other hand, the protoporphyrin IX-loaded TEL liposomes showed lower phototoxicity (IC50 of $12 \mu \mathrm{M}$ ) when tested on mouse fibroblasts.

Ali et al. reported developing different liposomal formulations accommodating temoporfin (second-generation, synthetic, effective PS) with enhanced phototoxicity against SK-OV-3 cancer cells [64]. Three liposomal formulations loaded with temoporfin (mTHPC) were prepared with molar ratios of 90 DPPC: 10 Cholesterol (DPPC/Chol/T), 95 DPPC: 5 DPPE-mPEG5000 (DPPC/DPPE mPEG5000/T), and 90 DPPC: 10 TEL (DPPC/TEL/T). The prepared liposomes had an average size range of $115 \mathrm{~nm}$ and zeta potentials ranging from -6.0 to $-13.7 \mathrm{mV}$. The $\% E E$ was $78 \pm 4,81.7 \pm 3$, and $90 \pm 3 \%$ for $\mathrm{DPPC} / \mathrm{Chol} / \mathrm{T}$, DPPC/DPPE mPEG5000/T and DPPC/TEL/T, respectively. The cell viability of SK-OV-3 cancer cells was reduced to $20 \%$ in the three liposomal formulations loaded with temoporfin when exposed to LED light of $10 \mathrm{~J} / \mathrm{cm}^{2}$. Moreover, all the designed liposomal formulations exhibited hemocompatibility ( $<10 \%$ hemolysis) and a coagulation time $<40 \mathrm{~s}$.

\subsubsection{Stealth Liposomes}

Stealth liposomes (PEGylated liposomes) are developed by the adsorption of PEGylated lipids (e.g., DPPE mPEG5000) on the liposomal surface, which prolongs the half-life of liposomes in circulation [65]. Steric hindrance occurs due to PEG reduces liposomal uptake by the reticuloendothelial system and their elimination via renal globular filtration. Moreover, the inclusion of the PEGylated lipids in the liposomal formulations improves their hydrophilicity, and hence, their shelf life [65].

In a different study, curcumin was loaded into liposomes comprising 9.5 HSPC: 0.5 DPPE mPEG5000 HCPC inhibits the leakage of curcumin outside the lipid membranes by imparting rigidity to the liposomal bilayer membrane [66]. The prepared liposomes exhibited significant phototoxic activity against skin cancer melanoma cells (MUG-Mel2) and squamous cell carcinoma (SCC-25) compared to free curcumin after exposure to LED light fluence of $2.5 \mathrm{~J} / \mathrm{cm}^{2}$. The cytotoxicities were 53\% (against MUG-Mel2) and 58\% (against SCC-25) for curcumin-loaded liposomal mediated PDT compared to 27\% (against MUG-Mel2) and 34\% (against SCC-25) for free curcumin (10 $\mu \mathrm{M})$ mediated PDT. The cytotoxic activity of the liposomal preparation against normal keratinocyte cells (HaCaT) was $11 \%$, highlighting the safety of the designed liposomes. Flow cytometry showed that integration of PDT with liposome encapsulating curcumin increased apoptosis to $30 \%$ and $40 \%$ in MUG-Mel2 and SCC-25 cancer cells, respectively.

A study conducted by Corato et al. loaded iron oxide nanoparticles in the aqueous liposomal core and mTHPC PS in the lipid bilayer [67]. The dual-loaded liposomes were prepared with a molar ratio of 85 DPPC: 10 DSPC: 5 DPPE mPEG5000, which was then mixed with $3.3 \mathrm{mg} / \mathrm{mL}$ mTHPC and $0.7 \mathrm{M}$ iron oxide NPs utilizing the reverse-phase evaporation approach. The prepared magneto-photoresponsive liposomes had a spherical structure, an average particle diameter of $150 \mathrm{~nm}$, and one-month stability at $4{ }^{\circ} \mathrm{C}$. The in vitro cell viability was assessed against SK-OV-3 cancer cells after exposure to either magnetic hyperthermia alone, PDT alone, or combined therapies. The \% cell viabilities were $10 \%$ after exposure to magnetic hyperthermia alone, 5 and $1 \%$ after exposure to PDT alone (at 5 and $10 \mathrm{~J}$, respectively), 0.2 and $0 \%$ after treatment with the liposomes loaded with iron oxide in the core and mTHPC in the aqueous layer/PDT (at 5 and $10 \mathrm{~J}$, respectively). As supported by proteomic analysis, the dual-loaded liposomes seem to activate intrinsic apoptotic pathways by increasing ROS levels and mitochondrial damage. 
Fisher et al. reported the design of lapatinib-loaded PEGylated liposomes for low-dose PDT of the invasive and resistant glioma [68]. Lapatinib is an antineoplastic, clinically approved PS that acts as an epidermal growth factor receptor (EGFR) inhibitor; however, it has poor penetration into glioma cells. PEGylated liposomes were prepared by mixing DPPC: DOTAP (1,2-dioleoyl-3-trimethylammonium-propane): cholesterol: DSPE-mPEG 2000 at a molar ratio of 0.6:0.079:0.289:0.031. The prepared liposomes had an average particle diameter of $132 \pm 9 \mathrm{~nm}$, a zeta potential of $14.3 \pm 0.8 \mathrm{mV}$, and \%EE of $64.5 \pm 8 \%$. The moderately positive charge aids electrostatic attraction of liposomes to the anionic cells leading to increased lapatinib uptake. The phototoxicity of the nanoformulation loaded with lapatinib and ALA (the latter is metabolized in vivo to protoporphyrin IX) was assessed against human glioblastoma cancer cell lines (U87 and U87vIII) irradiated with $635 \mathrm{~nm}$ light provided by a laser at a light dose of $65 \mathrm{~mW} / \mathrm{cm}^{2}$. A remarkable reduction $(46 \%)$ in the LD50 in the case of lapatinib-loaded liposomes compared to the free lapatinib was observed.

Peng et al. designed long-circulating dual-loaded PEGylated liposomes loaded with Chlorin e6 PS and cisplatin, a first-generation platinum-based chemotherapeutic drug (PL-Ce6-Cis) [69]. In this context, the hydrophilic cisplatin was loaded in the aqueous liposomal core, while hydrophobic Ce6 was incorporated in the outer lipid bilayer. The dual-loaded PEGylated liposomes were prepared with a molar ratio of 10 DSPC:0.2 DSPEPEG2000:5 cholesterol using the ethanol injection approach. A single dose of the dualloaded liposomes integrated with light irradiation with a fluence of $100 \mathrm{~J} / \mathrm{cm}^{2}$ could kill $80 \%$ of C26 colon cancer cells (compared to only $20 \%$ without irradiation), while maintaining minimal adverse toxic effects.

Another recent study reported the use of combined chemotherapy and PDT using dual-loaded PL-Ce6-Cis to treat malignant peripheral nerve sheath cancer (MPNST) [70]. In this regard, the cytotoxicity assessment was conducted against three different MPNST cancer cell lines (T265, ST8814, and S462-TY), derived from NF1 patients using a $662 \mathrm{~nm}$ diode laser with a power intensity of $95 \mathrm{~mW}$. The cell viability was reduced significantly $(<40 \%$ ) for PL-Ce6-Cis compared to PL-Ce6 or PL-Cis. Moreover, the PL-Ce6-Cis dualmodal formulation was found to exert minimal neurotoxicity.

\subsubsection{Thermosensitive Liposomes (TSLs)}

Thermosensitive liposomes (TSLs) are used for triggered release delivery into solid tumors, with at least one formulation currently under phase III clinical trials [71-74]. Exposure to mild hyperthermia $\left(39-43^{\circ} \mathrm{C}\right)$, causes a phase change of the liposomal lipid bilayer from a solid gel well-arranged phase $\left(\mathrm{L}_{\beta}\right)$ to a fluid tangled phase $\left(\mathrm{L}_{\alpha}\right)$. This results in enhanced membrane permeability, thus facilitating the release of the liposomal cargo into cancer cells [75-77]. It is of note that the lipid composition of liposomes is key in the TSLs temperature-triggered drug release [78]. Drug release occurs at temperatures equal or lower (by $1-2{ }^{\circ} \mathrm{C}$ ) to the melting phase transition temperature (Tm) of lipids where structural deformations in the lipid membrane increase the membrane permeability of the lipid bilayer, facilitating the release of the liposomal drug content $[79,80]$. DPPC, for instance, has a Tm slightly higher than normal body temperature (about $41^{\circ} \mathrm{C}$ ), and is, thus, used for TSL systems [78].

Shemesh et al. developed an integrated thermosensitive liposomes (TSLs)/PDT encapsulating indocyanine green PS (ICG) to treat triple-negative breast cancer [81]. The TSLs are designed by mixing a molar ratio of 100 DPPC:50 SoyPC (1- $\alpha$-phosphatidylcholine):30 Chol:0.5 DSPE-PEG 2000 using the thin-film hydration method. The prepared TSLs had an average particle diameter of $71 \pm 10 \mathrm{~nm}$ and could encapsulate $\sim 500 \mu \mathrm{M}$ of ICG. The TSLs loaded with ICG $(37.5 \mu \mathrm{M})$ demonstrated significant cytotoxicity (cell viability < 20\%) against MDA-MB-468 and HCC-1806 cells at laser radiation of $14 \mathrm{~J} / \mathrm{cm}^{2}$ compared to free ICG [81].

Meng et al. combined chemotherapy, immunotherapy, and PDT to treat gastric cancer [82]. Thermosensitive liposomes were loaded with IR820 PS, paclitaxel anticancer drug, 
and imiquimod (R837) (Figure 4). IR820 PS is derived from ICG and is more stable, less expensive, and suitable for photothermal and photodynamic therapies [83,84]. Imiquimod (R837), a dendritic cell activator, is an agonist to TLR7 and has immunomodulatory activities [85]. Mouse fore-stomach carcinoma cell (MFC) treated with the designed liposomes and irradiated with $808 \mathrm{~nm}$ light provided by a laser at a light dose of $2.5 \mathrm{~W} / \mathrm{cm}^{2}$ showed that the cell viability decreased to $10 \%$ (Figure 5).

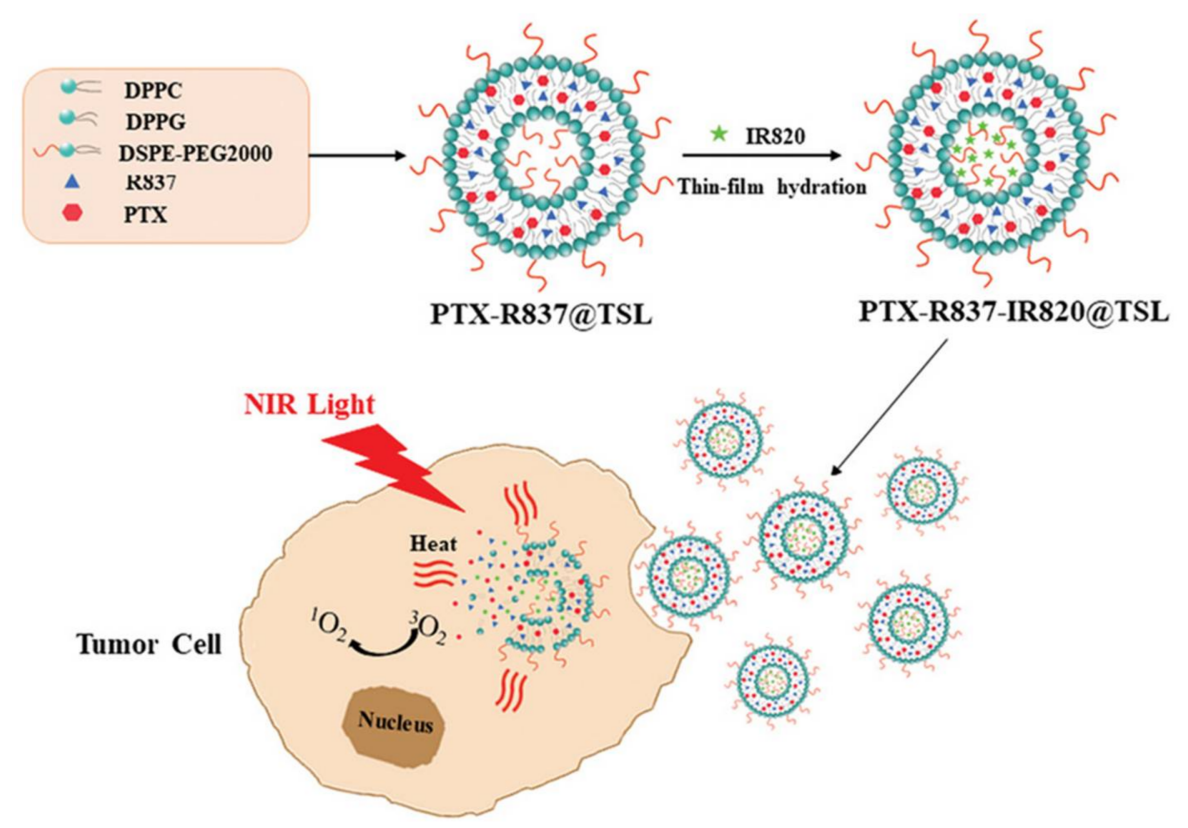

Figure 4. Thermosensitive liposomes loaded with IR820 PS, paclitaxel, and imiquimod (R837) [81]. DPPC, 1,2-Dipalmitoyl-sn-glycero-3-phosphocholine; DPPG, 1,2-Dipalmitoyl-snglycero-3-phosphoglycerol, sodium salt; 1,2-distearoyl-sn-glycero-3-phosphoethanolamine-N[amino(polyethylene glycol)-2000] (ammonium salt); R827, imiquimod; PTX, Paclitaxel; IR820, photosensitizer. Reprinted with permission from ref. [82]. 2019 Meng et al.

\subsubsection{Miscellaneous Liposomes}

A study reported developing a novel multimodal delivery system, lipopolyplexes (LPPs) loaded with curcumin, combined with PDT for improving gene delivery to SKOV-3 cancer cells [86]. LPPs used comprised cationic polyethyleneimine and luciferaseexpressing pCMV-luc plasmid with anionic liposomes in a ratio of 1:0.5. Liposomes were formulated with a molar ratio of 70 DOPE: 15 DPPC: 15 cholesterol. The designed LPPs loaded with curcumin were spherical and had a particle size of $200 \mathrm{~nm}$ and zeta potential of $+8.6 \mathrm{mV} \pm 1.7 \mathrm{mV}$. Treatment of SK-OV-3 cells with LPPs loaded with curcumin and irradiation with LED light at $457 \mathrm{~nm}$ (irradiation fluence of $1 \mathrm{~J} / \mathrm{cm}^{2}$ ) resulted in a significant increase in luciferase expression. The designed LPPs had minimal hemolytic effects and plasma coagulation time of $32 \mathrm{~s}$.

Another recent study reported PDT combined with curcumin-loaded magnetic/ photoresponsive liposomes (MPLs) in treating papillomavirus-related cancers (Figure 5) [87]. Citric acid-coated iron oxide (CMNPs) magnetic nanoparticles are synthesized employing the chemical precipitation method [88]. Liposomes were prepared using thin-film hydration technique and lipid mixtures in a molar ratio of 5 DSPC: 3 Chol: 1 DDAB $(1,2-$ stearoyl-sn-glycero-3-phosphocholine, dimethyl octadecyl ammonium bromide). In the hydration step, the thin film was hydrated with $0.3 \mathrm{mg} / \mathrm{mL}$ CMNPs, $50 \mu \mathrm{g} / \mathrm{mL}$ ICG, producing the ICG-loaded magnetic liposomes. Liposomes were then coated with hyaluronic acid-polyethylene glycol (HA-PEG) PS via sonication. Interactions between anionic HA and the cationic DDAB were responsible for the self-assembly of HA-PEG on the surface of MPLs. HA binds to the over-expressed CD44 receptors on the cell surface of human primary glioblastoma cancer cells (U87MG). The designed HA-PEG MPLs had an average 
particle size of about $220 \mathrm{~nm}$ and exhibited significant cytotoxicity (cell viability of $\sim 30 \%$ at a concentration of $2 \mathrm{mg} / \mathrm{mL}$ ) against U87MG after exposure to near-infrared laser radiation of $2 \mathrm{~W} / \mathrm{cm}^{2}$. Moreover, a xenograft tumor model designed by subcutaneous implantation of U87MG cells in nude mice showed the accumulation of HA-PEG MPLs in cancerous tissues. Following laser irradiation, the tumor size was reduced by $13 \%$ compared to the control (Figure 5).

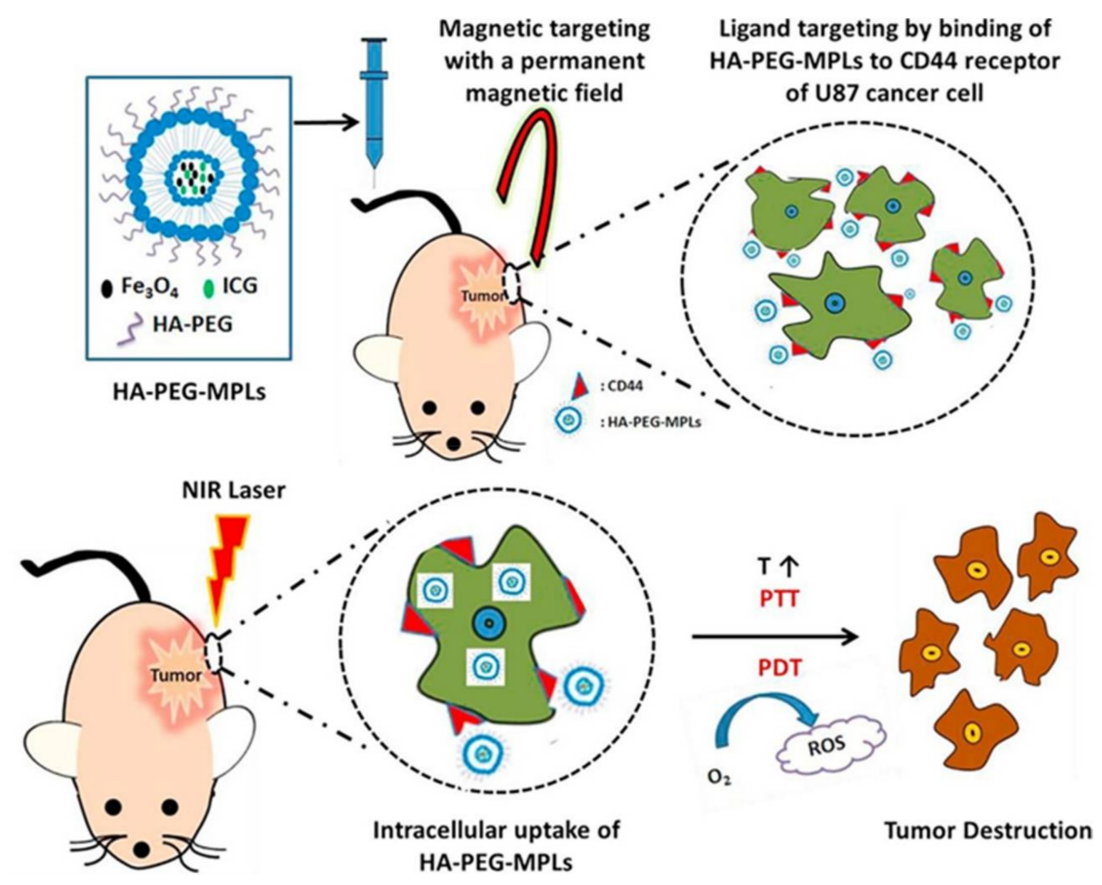

Figure 5. Schematic illustration of HA-PEG coated magnetic/photoresponsive liposomes for combined photothermal/photodynamic cancer therapy. ICG, Indocyanin green PS; HA-PEG, hyaluronic acid-polyethylene glycol; MPLs, magnetic/photoresponsive liposomes; PTT, photothermal therapy; ROS, reactive oxygen species. Reprinted with permission from ref. [87]. 2019 Meng et al.

Another recent study reported the encapsulation of ICG in chitosan-coated liposomes for PDT of melanoma. Chitosan coating has imparted stability to liposomes and improved their cellular uptake into B16-F10 melanoma cancer cells [89]. The liposomes were designed with a molar ratio of 16 DMPC: 3 Chol using the modified freeze-drying method. The positively charged chitosan $(0.1 \%)$ coated the anionic liposomal surface through electrostatic interactions. The prepared chitosan-coated liposomes loaded with ICG had a mean droplet size of $1983 \pm 270 \mathrm{~nm}$, a zeta potential of $43.2 \pm 1.2$, and a loaded ICG concentration of $1.19 \pm 0.03 \mathrm{mg} / \mathrm{mL}$. Cellular uptake of ICG was dramatically increased (owing to the cationic nature of chitosan coats). Moreover, the prepared liposomes showed remarkable phototoxicity against B16-F10 cancer cells after exposure to laser (775 nm) at a power of $0.23 \mathrm{~mW}$ for $2.5 \mathrm{~min}$.

A study conducted by $\mathrm{Wu}$ et al. reported the preparation of zwitterionic liposomes encapsulating methylene blue (MB) PS that can generate ROS after light exposure and causing cancer cell apoptosis [90]. MB has poor penetration into cancer cells; hence, this study aimed to encapsulate MB into zwitterionic liposomes to protect loaded drugs from degradation, prolong systemic circulation, and enhance cellular uptake. A zwitterionic polymer-lipid poly(12-(methacryloyloxy) dodecyl phosphorylcholine) was self-assembled with DSPC in a molar ratio of 1:4. The prepared zwitterionic liposomes had an average particle size of $150 \mathrm{~nm}$ and fast release rates (about $90 \%$ of the MB was released over $8 \mathrm{~h}$ ). A significant increase in the ROS release was observed in the case of MB-loaded liposomes compared to the unloaded MB. Increased cytotoxicity of the MB-loaded zwitterionic liposomes was observed against breast cancer cells (4T1 cells) compared to unloaded MB 
irradiated with LED light $(660 \mathrm{~nm})$ of $165 \mathrm{~mW}$ for $6 \mathrm{~min}$. Annexin V-FITC assay showed that cytotoxicity took place via apoptosis.

Finally, Rizvi et al. prepared two liposomal formulations encapsulating Visudyne or a lipid conjugate of BPD. These formulations were combined to localize the PSs and cause photodamage (following irradiation with a $690 \mathrm{~nm}$ diode laser at a light dose of $50 \mathrm{~mW} / \mathrm{cm}^{2}$ ) to mitochondria, endoplasmic reticulum, and lysosomes in a 3D model of ovarian cancer [91]. The recent studies in integrating liposomes with PDT in cancer treatment are summarized in Table 3.

Table 3. Encapsulation of PSs into liposomes in cancer PDT.

\begin{tabular}{|c|c|c|c|c|c|c|}
\hline Liposomes & $\begin{array}{l}\text { Liposomal } \\
\text { Formulation }\end{array}$ & PS & Light Dose & Tumor Type & Outcomes & Ref \\
\hline \multirow{5}{*}{ Tetraether liposomes } & $\begin{array}{l}\text { DSPC } \\
\text { TELs }\end{array}$ & Curcumin & $13.2 \mathrm{~J} / \mathrm{cm}^{2}$ & $\begin{array}{l}\text { Ovarian cancer } \\
\text { (SK-OV-3) }\end{array}$ & $\begin{array}{ll}\text { - } & \text { Enhanced } \\
\text { photocytotoxicity. } \\
\text { - } \quad \text { Minimal hemolytic } \\
\text { effect. }\end{array}$ & [59] \\
\hline & $\begin{array}{l}\text { DSPC } \\
\text { TELs }\end{array}$ & Curcumin & $\begin{array}{l}1,3 \text {, and } \\
5 \mathrm{~J} / \mathrm{cm}^{2}\end{array}$ & $\begin{array}{l}\text { Papillomavirus- } \\
\text { related cancer } \\
\text { cell lines }\end{array}$ & $\begin{array}{l}\text { Enhanced } \\
\text { cytotoxicity, reduced } \\
\text { colony formation, } \\
\text { proliferation, and cell } \\
\text { migration rates. }\end{array}$ & [60] \\
\hline & $\begin{array}{l}\text { DPPC } \\
\text { TELs }\end{array}$ & Hypericin & $12.4 \mathrm{~J} / \mathrm{cm}^{2}$ & SK-OV-3 & $\begin{array}{ll}\text { - } & \text { Enhanced } \\
\text { photocytotoxicity. } \\
\text { - } \quad \text { High cancer cell } \\
\text { uptake. } \\
\text { - } \quad \text { Hemocompatibility. }\end{array}$ & [61] \\
\hline & TELs & $\begin{array}{l}\text { Protoporphyrin } \\
\text { IX }\end{array}$ & $672 \mathrm{~mJ} / \mathrm{cm}^{2}$ & SK-OV-3 & $\begin{array}{l}\text { Improvement of } \\
\text { phototoxicity on } \\
\text { cancer cells while } \\
\text { maintaining lower } \\
\text { phototoxicity on } \\
\text { normal cells. }\end{array}$ & [63] \\
\hline & $\begin{array}{l}\text { DPPC } \\
\text { TELs }\end{array}$ & $\begin{array}{l}\text { Temoporfin } \\
\text { (mTHPC) }\end{array}$ & $10 \mathrm{~J} / \mathrm{cm}^{2}$ & SK-OV-3 & $\begin{array}{ll}\text { - } & \text { Enhanced } \\
& \text { cytotoxicity. } \\
\text { - } & \text { Hemocompatibility. }\end{array}$ & [64] \\
\hline \multirow{4}{*}{ Stealth Liposomes } & $\begin{array}{l}\text { DPPC } \\
\text { DPPE- } \\
\text { mPEG5000 }\end{array}$ & $\begin{array}{l}\text { Temoporfin } \\
\text { (mTHPC) }\end{array}$ & $10 \mathrm{~J} / \mathrm{cm}^{2}$ & SK-OV-3 & $\begin{array}{l}\text { Enhanced } \\
\text { cytotoxicity. } \\
\text { Hemocompatibility. }\end{array}$ & [64] \\
\hline & $\begin{array}{l}\text { HSPC } \\
\text { DPPE mPEG5000 }\end{array}$ & Curcumin & $2.5 \mathrm{~J} / \mathrm{cm}^{2}$ & $\begin{array}{l}\text { Skin cancer } \\
\text { melanoma cells } \\
\text { (MUG-Mel2) and } \\
\text { squamous cell } \\
\text { carcinoma } \\
\text { (SCC-25) }\end{array}$ & $\begin{array}{l}\text { Enhanced } \\
\text { cytotoxicity on } \\
\text { cancer cells. } \\
\text { Lower cytotoxicity } \\
\text { on normal } \\
\text { keratinocyte cells. }\end{array}$ & [66] \\
\hline & $\begin{array}{l}\text { DPPC } \\
\text { DSPC: DPPE } \\
\text { mPEG5000 }\end{array}$ & mTHPC & 5 and $10 \mathrm{~J} / \mathrm{cm}^{2}$ & SK-OV-3 & $\begin{array}{l}\text { Enhanced } \\
\text { cytotoxicity on } \\
\text { cancer cells. }\end{array}$ & [67] \\
\hline & $\begin{array}{l}\text { DPPC } \\
\text { DOTAP }\end{array}$ & Lapatinib & $65\left(\mathrm{~mW} / \mathrm{cm}^{2}\right)$ & $\begin{array}{l}\text { Human } \\
\text { glioblastoma } \\
\text { cancer cell lines } \\
\text { (U87, U87vIII) }\end{array}$ & $\begin{array}{l}\text { Remarkable } \\
\text { reduction in the } \\
\text { LD50. }\end{array}$ & [68] \\
\hline
\end{tabular}


Table 3. Cont.

\begin{tabular}{|c|c|c|c|c|c|c|c|c|}
\hline \multicolumn{2}{|l|}{ Liposomes } & \multirow{2}{*}{$\begin{array}{l}\begin{array}{l}\text { Liposomal } \\
\text { Formulation }\end{array} \\
\text { DSPC } \\
\text { DSPE-PEG2000 } \\
\text { Cholesterol }\end{array}$} & \multirow{2}{*}{$\begin{array}{l}\text { PS } \\
\text { Chlorin e6 }\end{array}$} & \multirow{2}{*}{$\begin{array}{l}\text { Light Dose } \\
100 \mathrm{~J} / \mathrm{cm}^{2}\end{array}$} & \multirow{2}{*}{$\begin{array}{l}\text { Tumor Type } \\
\text { C26 colon cancer } \\
\text { cells }\end{array}$} & \multicolumn{2}{|c|}{ Outcomes } & \multirow{2}{*}{$\begin{array}{l}\text { Ref } \\
{[69]}\end{array}$} \\
\hline & & & & & & - & $\begin{array}{l}\text { Kills } 80 \% \text { of the } \mathrm{C} 26 \\
\text { colon cancer cells. } \\
\text { Minimum adverse } \\
\text { reactions. }\end{array}$ & \\
\hline & & $\begin{array}{l}\text { DSPC } \\
\text { DPPE mPEG5000 } \\
\text { Cholesterol }\end{array}$ & Chlorin e6 & $95 \mathrm{~mW} / \mathrm{cm}^{2}$ & $\begin{array}{l}\text { Malignant } \\
\text { peripheral nerve } \\
\text { sheath cancer }\end{array}$ & - & $\begin{array}{l}\text { Enhanced } \\
\text { cytotoxicity on } \\
\text { cancer cells. } \\
\text { Minimal } \\
\text { neurotoxicity. }\end{array}$ & [70] \\
\hline \multirow{2}{*}{\multicolumn{2}{|c|}{$\begin{array}{l}\text { Thermosensitive } \\
\text { liposomes }\end{array}$}} & $\begin{array}{l}\text { DPPC } \\
\text { SoyPC } \\
\text { Chol } \\
\text { DSPE-PEG } 2000\end{array}$ & ICG & $14 \mathrm{~J} / \mathrm{cm}^{2}$ & $\begin{array}{l}\text { Triple-negative } \\
\text { breast cancer } \\
\text { (MDA-MB-468 } \\
\text { and HCC-1806 } \\
\text { cells) }\end{array}$ & & $\begin{array}{l}\text { Significant } \\
\text { cytotoxicity } \\
\text { compared to free PS }\end{array}$ & [81] \\
\hline & & $\begin{array}{l}\text { DPPC } \\
\text { DPPG } \\
\text { DPPE mPEG5000 }\end{array}$ & IR820 & $2.5 \mathrm{~W} / \mathrm{cm}^{2}$ & $\begin{array}{l}\text { mouse } \\
\text { fore-stomach } \\
\text { carcinoma cell } \\
(\mathrm{MFC})\end{array}$ & & $\begin{array}{l}\text { Significant } \\
\text { cytotoxicity }\end{array}$ & [82] \\
\hline \multirow{4}{*}{$\begin{array}{l}\text { Miscellane } \\
\text { ous } \\
\text { Liposomes }\end{array}$} & $\begin{array}{l}\text { Lipopolyple } \\
\text { xes (LPPs) }\end{array}$ & $\begin{array}{l}\text { DOPC } \\
\text { DPPC } \\
\text { Cholesterol }\end{array}$ & Curcumin & $1 \mathrm{~J} / \mathrm{cm}^{2}$ & SK-OV-3 & $\begin{array}{l}- \\
-\end{array}$ & $\begin{array}{l}\text { Significant } \\
\text { enhancement in the } \\
\text { luciferase expression } \\
\text { of SK-OV-3. } \\
\text { Biocompatibility. }\end{array}$ & [86] \\
\hline & $\begin{array}{l}\text { Magnetic/ } \\
\text { photo- } \\
\text { responsive } \\
\text { liposomes }\end{array}$ & $\begin{array}{l}\text { DSPC } \\
\text { Cholesterol } \\
\text { DDAB }\end{array}$ & $\begin{array}{l}\text { Indocyanine } \\
\text { green (ICG) }\end{array}$ & $2 \mathrm{~J} / \mathrm{cm}^{2}$ & $\begin{array}{l}\text { Glioblastoma } \\
\text { cancer cells } \\
(\mathrm{U} 87 \mathrm{MG})\end{array}$ & & $\begin{array}{l}\text { Significant } \\
\text { cytotoxicity and } \\
\text { accumulation in } \\
\text { cancer cells. }\end{array}$ & [87] \\
\hline & $\begin{array}{l}\text { Chitosan- } \\
\text { coated } \\
\text { liposomes }\end{array}$ & $\begin{array}{l}\text { DMPC } \\
\text { Cholesterol }\end{array}$ & ICG & $250 \mathrm{~mW}$ & Melanoma & & $\begin{array}{l}\text { Improved } \\
\text { permeability and } \\
\text { phototoxicity. }\end{array}$ & [89] \\
\hline & $\begin{array}{l}\text { Zwitterionic } \\
\text { liposomes }\end{array}$ & $\begin{array}{l}\text { Poly-(12-meth- } \\
\text { acryloyloxy)- } \\
\text { dodecyl } \\
\text { phosphoryl- } \\
\text { choline } \\
\text { DSPC }\end{array}$ & $\begin{array}{l}\text { Methylene } \\
\text { blue (MB) }\end{array}$ & $165 \mathrm{~mW}$ & $\begin{array}{l}\text { Breast cancer } \\
\text { cells ( } 4 \mathrm{~T} 1 \text { cells) }\end{array}$ & - & $\begin{array}{l}\text { Enhanced } \\
\text { cytotoxicity on } \\
\text { cancer cells. } \\
\text { Improved safety. }\end{array}$ & [90] \\
\hline
\end{tabular}

\section{Conclusions}

In this paper, we reviewed the most recent state-of-the-art studies concerning the use of integrated liposomes/PDT for effective cancer PDT. The ability of liposomes to accommodate hydrophilic and hydrophobic photosensitizers in the aqueous interior and the outer lipid bilayer, respectively, make them top candidates for the delivery of PSs in cancer PDT. Besides, liposomes can target the loaded PSs to cancer cells via active or passive targeting. Moreover, liposome surfaces could be decorated with particular ligands that recognize and bind to overexpressed receptors and proteins in tumor tissues, such as folate, estrogen, spermine, and galactose receptors. Liposomes were also found to improve the selective targeting of PS alone or combined with other chemotherapeutic drugs, hence minimizing their toxic effects. Several studies have reported the enhanced effectiveness of PDT upon encapsulation of PSs in different liposomal formulations. Therefore, these combinatorial/multimodal platforms are likely promising candidates that can improve the effectiveness of cancer PDT. 
Author Contributions: Conceptualization, S.A.F., H.M.E.-S.A. and J.S.; methodology, S.A.F.; data curation, S.A.F.; writing-original draft preparation, S.A.F.; writing-review and editing, S.A.F., H.M.E.-S.A. and J.S.; supervision, H.M.E.-S.A. and J.S.; project administration, H.M.E.-S.A. and J.S. All authors have read and agreed to the published version of the manuscript.

Funding: This work has been funded by a grant from the American University in Cairo to H.M.E.-S.A.

Institutional Review Board Statement: Not applicable.

Informed Consent Statement: Not applicable.

Conflicts of Interest: The authors declare no conflict of interest.

\section{References}

1. Filipczak, N.; Pan, J.; Yalamarty, S.S.; Torchilin, V.P. Recent advancements in liposome technology. Adv. Drug Deliv. Rev. 2020, 156, 4-22. [CrossRef]

2. Jhaveri, A.; Deshpande, P.; Torchilin, V. Stimuli-sensitive nanopreparations for combination cancer therapy. J. Control. Release 2014, 190, 352-370. [CrossRef]

3. Fahmy, S.A.; Ponte, F.; Sicilia, E.; Azzazy, H.M. Experimental and Computational Investigations of Carboplatin Supramolecular Complexes. ACS Omega 2020, 5, 31456-31466. [CrossRef]

4. Fahmy, S.A.; Ponte, F.; Fawzy, I.M.; Sicilia, E.; Bakowsky, U.; Azzazy, H.S. Host-Guest Complexation of Oxaliplatin and Para-Sulfonatocalix[n]Arenes for Potential Use in Cancer Therapy. Molecules 2020, 25, 5926. [CrossRef]

5. Duse, L.; Baghdan, E.; Pinnapireddy, S.R.; Engelhardt, K.H.; Jedelská, J.; Schaefer, J.; Quendt, P.; Bakowsky, U. Preparation and Characterization of Curcumin Loaded Chitosan Nanoparticles for Photodynamic Therapy. Phys. Status Solidi A 2018, 215, 1700709. [CrossRef]

6. Fahmy, S.A.; Preis, E.; Bakowsky, U.; Azzazy, H.M. Palladium Nanoparticles Fabricated by Green Chemistry: Promising Chemotherapeutic, Antioxidant and Antimicrobial Agents. Materials 2020, 13, 3661. [CrossRef] [PubMed]

7. Lim, M.E.; Lee, Y.L.; Zhang, Y.; Chu, J.J. Photodynamic inactivation of viruses using upconversion nanoparticles. Biomaterials 2012, 33, 1912-1920. [CrossRef]

8. Li, X.; Lee, S.; Yoon, J. Supramolecular photosensitizers rejuvenate photodynamic therapy. Chem. Soc. Rev. 2018, 47, 1174-1188 [CrossRef] [PubMed]

9. Kwiatkowski, S.; Knap, B.; Przystupski, D.; Saczko, J.; Kędzierska, E.; Knap-Czop, K.; Kotlinska, J.; Michel, O.; Kotowski, K.; Kulbacka, J. Photodynamic therapy-Mechanisms, photosensitizers and combinations. Biomed. Pharmacother. 2018, 106, 1098-1107. [CrossRef]

10. Sun, J.; Kormakov, S.; Liu, Y.; Huang, Y.; Wu, D.; Yang, Z. Recent Progress in Metal-Based Nanoparticles Mediated Photodynamic Therapy. Molecules 2018, 23, 1704. [CrossRef]

11. Chizenga, E.P.; Chandran, R.; Abrahamse, H. Photodynamic therapy of cervical cancer by eradication of cervical cancer cells and cervical cancer stem cells. Oncotarget 2019, 10, 4380-4396. [CrossRef]

12. Dolmans, D.E.; Fukumura, D.; Jain, R.K. Photodynamic therapy for cancer. Nat. Rev. Cancer 2003, 3, 380-387. [CrossRef]

13. Preis, E.; Baghdan, E.; Agel, M.R.; Anders, T.; Pourasghar, M.; Schneider, M.; Bakowsky, U. Spray dried curcumin loaded nanoparticles for antimicrobial photodynamic therapy. Eur. J. Pharm. Biopharm. 2019, 142, 531-539. [CrossRef]

14. Preis, E.; Anders, T.; Širc, J.; Hobzova, R.; Cocarta, A.I.; Bakowsky, U.; Jedelská, J. Biocompatible indocyanine green loaded PLA nanofibers for in situ antimicrobial photodynamic therapy. Mater. Sci. Eng. C Mater. Biol. Appl. 2020, 115, 111068. [CrossRef]

15. Lucky, S.S.; Soo, K.C.; Zhang, Y. Nanoparticles in photodynamic therapy. Chem. Rev. 2015, 115, 1990-2042. [CrossRef] [PubMed]

16. Polat, E.; Kang, K. Natural Photosensitizers in Antimicrobial Photodynamic Therapy. Biomedicines 2021, 9, 584. [CrossRef]

17. Park, W.; Cho, S.; Han, J.; Shin, H.; Na, K.; Lee, B.; Kim, D.H. Advanced smart-photosensitizers for more effective cancer treatment. Biomater. Sci. 2018, 6, 79-90. [CrossRef] [PubMed]

18. Stewart, F.; Baas, P.; Star, W. What does photodynamic therapy have to offer radiation oncologists (or their cancer patients)? Radiother. Oncol. 1998, 48, 233-248. [CrossRef]

19. Turksoy, A.; Yildiz, D.; Akkaya, E.U. Photosensitization and controlled photosensitization with BODIPY dyes. Coord. Chem. Rev. 2019, 379, 47-64. [CrossRef]

20. Valkov, A.; Zinigrad, M.; Nisnevitch, M. Photodynamic Eradication of Trichophyton rubrum and Candida albicans. Pathogens 2021, 10, 263. [CrossRef]

21. Ghate, V.S.; Zhou, W.; Yuk, H.G. Perspectives and Trends in the Application of Photodynamic Inactivation for Microbiological Food Safety. Compr. Rev. Food Sci. Food Saf. 2019, 18, 402-424. [CrossRef]

22. Bapat, P.; Singh, G.; Nobile, C.J. Visible Lights Combined with Photosensitizing Compounds Are Effective against Candida albicans Biofilms. Microorganisms 2021, 9, 500. [CrossRef]

23. Sun, H.; Feng, M.; Chen, S.; Wang, R.; Luo, Y.; Yin, B.; Li, J.; Wang, X. Near-infrared photothermal liposomal nanoantagonists for amplified cancer photodynamic therapy. J. Mater. Chem. B 2020, 8, 7149-7159. [CrossRef] [PubMed]

24. Azad, M.B.; Chen, Y.; Gibson, S.B. Regulation of autophagy by reactive oxygen species (ROS): Implications for cancer progression and treatment. Antioxid. Redox Signal. 2009, 11, 777-790. [CrossRef] [PubMed] 
25. Luby, B.M.; Walsh, C.D.; Zheng, G. Advanced Photosensitizer Activation Strategies for Smarter Photodynamic Therapy Beacons. Angew. Chem. Int. Ed. 2019, 58, 2558-2569. [CrossRef]

26. Calixto, G.M.; Bernegossi, J.; De Freitas, L.M.; Fontana, C.R.; Chorilli, M. Nanotechnology-Based Drug Delivery Systems for Photodynamic Therapy of Cancer: A Review. Molecules 2016, 21, 342. [CrossRef]

27. Das, S.; Tiwari, M.; Mondal, D.; Sahoo, B.R.; Tiwari, D.K. Growing tool-kit of photosensitizers for clinical and non-clinical applications. J. Mater. Chem. B 2020, 8, 10897-10940. [CrossRef]

28. Kleinovink, J.W.; van Driel, P.B.; Snoeks, T.J.; Prokopi, N.; Fransen, M.F.; Cruz, L.J.; Mezzanotte, L.; Chan, A.; Löwik, C.W.; Ossendorp, F. Combination of photodynamic therapy and specific immunotherapy efficiently eradicates established tumors. Clin. Cancer Res. 2016, 22, 1459-1468. [CrossRef]

29. Mfouo-Tynga, I.S.; Dias, L.D.; Inada, N.M.; Kurachi, C. Features of third generation photosensitizers used in anticancer photodynamic therapy: Review. Photodiagnosis Photodyn. Ther. 2021, 34, 102091. [CrossRef]

30. Li, Z.; Wang, Y.; Wang, J.; Li, S.; Xiao, Z.; Feng, Y.; Gu, J.; Li, J.; Peng, X.; Li, C.; et al. Evaluation of the efficacy of 5-aminolevulinic acid photodynamic therapy for the treatment of vulvar lichen sclerosus. Photodiagn. Photodyn. Ther. 2020, 29, 101596. [CrossRef] [PubMed]

31. Malik, Z. Fundamentals of 5-aminolevulinic acid photodynamic therapy and diagnosis: An overview. Transl. Biophotonics 2020, 2, e201900022. [CrossRef]

32. Alcántara-González, J.; Calzado-Villarreal, L.; Sánchez-Largo, M.E.; Andreu-Barasoain, M.; Ruano-Del Salado, M. Recalcitrant viral warts treated with photodynamic therapy methyl aminolevulinate and red light $(630 \mathrm{~nm})$ : A case series of 51 patients. Lasers Med. Sci. 2020, 35, 229-231. [CrossRef] [PubMed]

33. Fukuhara, H.; Yamamoto, S.; Karashima, T.; Inoue, K. Photodynamic diagnosis and therapy for urothelial carcinoma and prostate cancer: New imaging technology and therapy. Int. J. Clin. Oncol. 2021, 26, 18-25. [CrossRef] [PubMed]

34. Salgado, C.N.; Habigton, P.; Itasaki, N.; Scholz, D. Photodynamic Application of Hexvix for Cancer Therapy. Cell Mol. Biol. J. 2016, 1, 2 .

35. Kiesslich, T.; Berlanda, J.; Plaetzer, K.; Krammer, B.; Berr, F. Comparative characterization of the efficiency and cellular pharmacokinetics of Foscan ${ }^{\circledR}$ - and Foslip ${ }^{\circledR}$-based photodynamic treatment in human biliary tract cancer cell lines. Photochem. Photobiol.Sci. 2007, 6, 619-627. [CrossRef]

36. Van Straten, D.; Mashayekhi, V.; De Bruijn, H.S.; Oliveira, S.; Robinson, D.J. Oncologic photodynamic therapy: Basic principles, current clinical status and future directions. Cancers 2017, 9, 19. [CrossRef]

37. Chatterjee, D.K.; Fong, L.S.; Zhang, Y. Nanoparticles in photodynamic therapy: An emerging paradigm. Adv. Drug Deliv. Rev. 2008, 60, 1627-1637. [CrossRef]

38. Abrahamse, H.; Kruger, C.A.; Kadanyo, S.; Mishra, A. Nanoparticles for Advanced Photodynamic Therapy of Cancer. Photomed. Laser Surg. 2017, 35, 581-588. [CrossRef]

39. Yan, K.; Zhang, Y.; Mu, C.; Xu, Q.; Jing, X.; Wang, D.; Dang, D.; Meng, L.; Ma, J. Versatile Nanoplatforms with enhanced Photodynamic Therapy: Designs and Applications. Theranostics 2020, 10, 7287-7318. [CrossRef]

40. Alsaab, H.O.; Alghamdi, M.S.; Alotaibi, A.S.; Alzhrani, R.; Alwuthaynani, F.; Althobaiti, Y.S.; Almalki, A.H.; Sau, S.; Iyer, A.K. Progress in Clinical Trials of Photodynamic Therapy for Solid Tumors and the Role of Nanomedicine. Cancers 2020, $12,2793$. [CrossRef]

41. Yano, S.; Hirohara, S.; Obata, M.; Hagiya, Y.; Ogura, S.I.; Ikeda, A.; Kataoka, H.; Tanaka, M.; Joh, T. Current states and future views in photodynamic therapy. Photochem. Photobiol. C Photochem. Rev. 2011, 12, 46-67. [CrossRef]

42. Debele, T.A.; Peng, S.; Tsai, H.C. Drug carrier for photodynamic cancer therapy. Int. J. Mol. Sci. 2015, 16, 22094-22136. [CrossRef]

43. Tian, G.; Zhang, X.; Gu, Z.; Zhao, Y. Recent advances in upconversion nanoparticles-based multifunctional nanocomposites for combined cancer therapy. Adv. Mater. 2015, 27, 7692-7712. [CrossRef]

44. El-Shafie, S.; Fahmy, S.A.; Ziko, L.; Elzahed, N.; Shoeib, T.; Kakarougkas, A. Encapsulation of Nedaplatin in Novel PEGylated Liposomes Increases Its Cytotoxicity and Genotoxicity against A549 and U2OS Human Cancer Cells. Pharmaceutics 2020, 12, 863. [CrossRef]

45. Torchilin, V.P. Recent advances with liposomes as pharmaceutical carriers. Nat. Rev. Drug Discov. 2005, 4, 145-160. [CrossRef]

46. Kanasty, R.; Dorkin, J.R.; Vegas, A.; Anderson, D. Delivery materials for siRNA therapeutics. Nat. Mater. $2013,12,967-977$. [CrossRef]

47. Yin, H.; Kanasty, R.L.; Eltoukhy, A.A.; Vegas, A.J.; Dorkin, J.R.; Anderson, D.G. Non-viral vectors for gene-based therapy. Nat. Rev. Genet. 2014, 15, 541-555. [CrossRef]

48. Torchilin, V.P. Multifunctional, stimuli-sensitive nanoparticulate systems for drug delivery. Nat. Rev. Drug Discov. 2014, 13, 813-827. [CrossRef]

49. Almeida, B.; Nag, O.K.; Rogers, K.E.; Delehanty, J.B. Recent Progress in Bioconjugation Strategies for Liposome-Mediated Drug Delivery. Molecules 2020, 25, 5672. [CrossRef]

50. Alshehri, A.; Grabowska, A.; Stolnik, S. Pathways of cellular internalisation of liposomes delivered siRNA and effects on siRNA engagement with target mRNA and silencing in cancer cells. Sci. Rep. 2018, 8, 3748. [CrossRef]

51. Sadeghi, N.; Deckers, R.; Ozbakir, B.; Akthar, S.; Kok, R.J. Lammers T, Storm G. Influence of cholesterol inclusion on the doxorubicin release characteristics of lysolipid-based thermosensitive liposomes. Int. J. Pharm. 2018, 548, 778-782. [CrossRef] 
52. Bulbake, U.; Doppalapudi, S.; Kommineni, N.; Khan, W. Liposomal Formulations in Clinical Use: An Updated Review. Pharmaceutics 2017, 9, 12. [CrossRef]

53. La-Beck, N.M.; Liu, X.; Wood, L.M. Harnessing Liposome Interactions with the Immune System for the Next Breakthrough in Cancer Drug Delivery. Front. Pharmacol. 2019, 10, 220. [CrossRef] [PubMed]

54. Inglut, C.T.; Sorrin, A.J.; Kuruppu, T.; Vig, S.; Cicalo, J.; Ahmad, H.; Huang, H.C. Immunological and Toxicological Considerations for the Design of Liposomes. Nanomaterials 2020, 10, 190. [CrossRef]

55. Li, Y.; Cong, H.; Wang, S.; Yu, B.; Shen, Y. Liposomes modified with bio-substances for cancer treatment. Biomater. Sci. 2020, 8, 6442-6468. [CrossRef]

56. Shaheen, S.M.; Shakil Ahmed, F.R.; Hossen, M.N.; Ahmed, M.; Amran, M.S.; Ul-Islam, M.A. Liposome as a carrier for advanced drug delivery. Pak. J. Biol. Sci. 2006, 9, 1181-1191. [CrossRef]

57. Kazantzis, K.T.; Koutsonikoli, K.; Mavroidi, B.; Zachariadis, M.; Alexiou, P.; Pelecanou, M.; Politopoulos, K.; Alexandratou, E.; Sagnou, M. Curcumin derivatives as photosensitizers in photodynamic therapy: Photophysical properties and in vitro studies with prostate cancer cells. Photochem. Photobiol. Sci. 2020, 19, 193-206. [CrossRef] [PubMed]

58. Dev, A.; Srivastava, A.K.; Choudhury, S.R.; Karmakar, S. Nano-curcumin influences blue light photodynamic therapy for restraining glioblastoma stem cells growth. RSC Adv. 2016, 6, 95165-95168. [CrossRef]

59. Duse, L.; Pinnapireddy, S.R.; Strehlow, B.; Jedelská, J.; Bakowsky, U. Low level LED photodynamic therapy using curcumin loaded tetraether liposomes. Eur. J. Pharm. Biopharm. 2018, 126, 233-241. [CrossRef]

60. Ambreen, G.; Duse, L.; Tariq, I.; Ali, U.; Ali, S.; Pinnapireddy, S.R.; Bette, M.; Bakowsky, U.; Mandic, R. Sensitivity of Papilloma Virus-Associated Cell Lines to Photodynamic Therapy with Curcumin-Loaded Liposomes. Cancers 2020, 12, 3278. [CrossRef] [PubMed]

61. Plenagl, N.; Duse, L.; Seitz, B.S.; Goergen, N.; Pinnapireddy, S.R.; Jedelska, J.; Brüßler, J.; Bakowsky, U. Photodynamic therapyHypericin tetraether liposome conjugates and their antitumor and antiangiogenic activity. Drug Deliv. 2019, 26, 23-33. [CrossRef]

62. Galanou, M.C.; Theodossiou, T.A.; Tsiourvas, D.; Sideratou, Z.; Paleos, C.M. Interactive transport, subcellular relocation and enhanced phototoxicity of hypericin encapsulated in guanidinylated liposomes via molecular recognition. Photochem. Photobiol. 2008, 84, 1073-1083.

63. Mahmoud, G.; Jedelská, J.; Strehlow, B.; Omar, S.; Schneider, M.; Bakowsky, U. Photo-responsive tetraether lipids based vesicles for prophyrin mediated vascular targeting and direct phototherapy. Colloids Surf. B Biointerfaces 2017, 159, 720-728. [CrossRef]

64. Ali, S.; Amin, M.U.; Ali, M.Y.; Tariq, I.; Pinnapireddy, S.R.; Duse, L.; Goergen, N.; Wölk, C.; Hause, G.; Jedelská, J.; et al. Wavelength dependent photo-cytotoxicity to ovarian carcinoma cells using temoporfin loaded tetraether liposomes as efficient drug delivery system. Eur. J. Pharm. Biopharm. 2020, 150, 50-65. [CrossRef]

65. Bakowsky, H.; Richter, T.; Kneuer, C.; Hoekstra, D.; Rothe, U.; Bendas, G.; Ehrhardt, C.; Bakowsky, U. Adhesion characteristics and stability assessment of lectin-modified liposomes for site-specific drug delivery. Biochim. Biophys. Acta 2008, 1778, 242-249. [CrossRef]

66. Woźniak, M.; Nowak, M.; Lazebna, A.; Więcek, K.; Jabłońska, I.; Szpadel, K.; Grzeszczak, A.; Gubernator, J.; Ziółkowski, P. The Comparison of In Vitro Photosensitizing Efficacy of Curcumin-Loaded Liposomes Following Photodynamic Therapy on Melanoma MUG-Mel2, Squamous Cell Carcinoma SCC-25, and Normal Keratinocyte HaCaT Cells. Pharmaceuticals 2021, 14, 374. [CrossRef] [PubMed]

67. Corato, R.D.; Béalle, G.; Kolosnjaj-Tabi, J.; Espinosa, A.; Clément, O.; Silva, A.K.; Ménager, C.; Wilhelm, C. Combining Magnetic Hyperthermia and Photodynamic Therapy for Tumor Ablation with Photoresponsive Magnetic Liposomes. ACS Nano 2015, 9 , 2904-2916. [CrossRef]

68. Fisher, C.; Obaid, G.; Niu, C.; Foltz, W.; Goldstein, A.; Hasan, T.; Lilge, L. Liposomal Lapatinib in Combination with Low-Dose Photodynamic Therapy for the Treatment of Glioma. J. Clin. Med. 2019, 8, 2214. [CrossRef]

69. Peng, P.C.; Hong, R.L.; Tsai, T.; Chen, C.T. Co-Encapsulation of Chlorin e6 and Chemotherapeutic Drugs in a PEGylated Liposome Enhance the Efficacy of Tumor Treatment: Pharmacokinetics and Therapeutic Efficacy. Pharmaceutics 2019, 11, 617. [CrossRef]

70. Chen, C.T.; Peng, P.C.; Tsai, T.; Chien, H.F.; Lee, M.J. A Novel Treatment Modality for Malignant Peripheral Nerve Sheath Tumor Using a Dual-Effect Liposome to Combine Photodynamic Therapy and Chemotherapy. Pharmaceutics 2020, 12, 317. [CrossRef]

71. Landon, C.D.; Park, J.Y.; Needham, D.; Dewhirst, M.W. Nanoscale drug delivery and hyperthermia: The materials design and preclinical and clinical testing of low temperature-sensitive liposomes used in combination with mild hyperthermia in the treatment of local cancer. Open Nanomed. J. 2011, 3, 38-64. [CrossRef]

72. Wust, P.; Hildebrandt, B.; Sreenivasa, G.; Rau, B.; Gellermann, J.; Riess, H.; Felix, R.; Schlag, P.M. Hyperthermia in combined treatment of cancer. Lancet Oncol. 2002, 3, 487-497. [CrossRef]

73. Huang, S.K.; Stauffer, P.R.; Hong, K.; Guo, J.W.; Phillips, T.L.; Huang, A.; Papahadjopoulos, D. Liposomes and hyperthermia in mice: Increased tumor uptake and therapeutic efficacy of doxorubicin in sterically stabilized liposomes. Cancer Res. 1994, 54, 2186-2191.

74. Manzoor, A.A.; Lindner, L.H.; Landon, C.D.; Park, J.Y.; Simnick, A.J.; Dreher, M.R.; Das, S.; Hanna, G.; Park, W.; Chilkoti, A.; et al. Overcoming limitations in nanoparticle drug delivery: Triggered, intravascular release to improve drug penetration into tumors. Cancer Res. 2012, 72, 5566-5575. [CrossRef]

75. Ta, T.; Porter, T.M. Thermosensitive liposomes for localized delivery and triggered release of chemotherapy. J. Control. Release 2013, 169, 112-125. [CrossRef] 
76. Lokerse, W.J.; Kneepkens, E.C.; ten Hagen, T.L.; Eggermont, A.M.; Grüll, H.; Koning, G.A. In depth study on thermosensitive liposomes: Optimizing systems for tumor specific therapy and in vitro to in vivo relations. Biomaterials 2016, 82, 138-150. [CrossRef]

77. Grüll, H.; Langereis, S. Hyperthermia-triggered drug delivery from temperature-sensitive liposomes using MRI-guided high intensity focused ultrasound. J. Control. Release 2012, 161, 317-327. [CrossRef]

78. Al-Ahmady, Z.; Kostarelos, K. Chemical components for the design of temperature responsive vesicles as cancer therapeutics. Chem. Rev. 2016, 116, 3883-3918. [CrossRef]

79. Li, L.; ten Hagen, T.L.; Schipper, D.; Wijnberg, T.M.; van Rhoon, G.C.; Eggermont, A.M.; Lindner, L.H.; Koning, G.A. Triggered content release from optimized stealth thermosensitive liposomes using mild hyperthermia. J. Control. Release 2010, 143, 274-279. [CrossRef]

80. Li, L.; Ten Hagen, T.L.; Bolkestein, M.; Gasselhuber, A.; Yatvin, J.; Van Rhoon, G.C.; Eggermont, A.M.; Haemmerich, D.; Koning, G.A. Improved intratumoral nanoparticle extravasation and penetration by mild hyperthermia. J. Control. Release 2013, 167, 130-137. [CrossRef]

81. Shemesh, C.S.; Hardy, C.W.; Yu, D.S.; Fernandez, B.; Zhang, H. Indocyanine green loaded liposome nanocarriers for photodynamic therapy using human triple negative breast cancer cells. Photodiagn. Photodyn. Ther. 2014, 11, 193-203. [CrossRef]

82. Meng, X.B.; Wang, K.; Lv, L.; Zhao, Y.; Sun, C.; Ma, L.J.; Zhang, B. Photothermal/Photodynamic Therapy with Immune-Adjuvant Liposomal Complexes for Effective Gastric Cancer Therapy. Part. Part. Syst. Charact. 2019, 36, 1900015. [CrossRef]

83. Wang, C.; Xu, L.; Liang, C.; Xiang, J.; Peng, R.; Liu, Z. Immunological Responses Triggered by Photothermal Therapy with Carbon Nanotubes in Combination with Anti-CTLA-4 Therapy to Inhibit Cancer Metastasis. Adv. Mater. 2014, 26, 8154. [CrossRef]

84. Feng, X.; Zhang, Y.; Wang, P.; Liu, Q.; Wang, X. Energy metabolism targeted drugs synergize with photodynamic therapy to potentiate breast cancer cell death. Photochem. Photobiol. Sci. 2014, 13, 1793. [CrossRef]

85. Berghöfer, B.; Frommer, T.; Haley, G.; Fink, L.; Bein, G.; Hackstein, H. TLR7 Ligands Induce Higher IFN- $\alpha$ Production in Females. J. Immunol. 2006, 177, 2088. [CrossRef]

86. Pinnapireddy, S.R.; Duse, L.; Akbari, D.; Bakowsky, U. Photo-Enhanced Delivery of Genetic Material Using Curcumin Loaded Composite Nanocarriers. Clin. Oncol. 2017, 2, 1323.

87. Anilkumar, T.S.; Lu, Y.J.; Chen, H.A.; Hsu, H.L.; Jose, G.; Chen, J.P. Dual targeted magnetic photosensitive liposomes for photothermal/photodynamic tumor therapy. J. Magn. Magn. Mater. 2018, 473, 241-252. [CrossRef]

88. Fahmy, S.A.; Alawak, M.; Brüßler, J.; Bakowsky, U.; El-Sayed, M.M. Nano-enabled Bioseparations: Current developments and future prospects. BioMed Res. Int. J. 2019, 2019, 4983291.

89. Lee, E.H.; Lim, S.J.; Lee, M.K. Chitosan-coated liposomes to stabilize and enhance transdermal delivery of indocyanine green for photodynamic therapy of melanoma. Carbohydr. Polym. 2019, 224, 115143. [CrossRef]

90. Wu, P.T.; Lin, C.L.; Lin, C.W.; Chang, N.C.; Tsai, W.B.; Yu, J. Methylene-Blue-Encapsulated Liposomes as Photodynamic Therapy Nano Agents for Breast Cancer Cells. Nanomaterials 2019, 9, 14. [CrossRef]

91. Rizvi, I.; Nath, S.; Obaid, G.; Ruhi, M.K.; Moore, K.; Bano, S.; Kessel, D.; Hasan, T. A Combination of Visudyne and a Lipidanchored Liposomal Formulation of Benzoporphyrin Derivative Enhances Photodynamic Therapy Efficacy in a 3D Model for Ovarian Cancer. Photochem. Photobiol. 2019, 95, 419-429. [CrossRef] 